\title{
The recovery of function and microcirculation in small intestinal loops following ischaemia ${ }^{1}$
}

\author{
J. W. L. ROBINSON AND V. MIRKOVITCH \\ From the Département de Chirurgie Expérimentale, Hôpital Cantonal Universitaire, Lausanne
}

SUMMARY Short loops of dog small intestine, filled with a buffered glucose solution, were subjected to one hour's total ischaemia by clamping the corresponding mesenteric artery and vein as well as the intestinal wall at each end of the loop. Immediately after the ischaemic period and 24 hours later, their functional capacity, together with that of neighbouring control loops, was determined by studying the absorption of phenylalanine and $\beta$-methyl-glucoside in vitro and by measuring the levels of $\mathrm{Na}^{+}-\mathrm{K}^{+}-\mathrm{ATPase}$ in the mucosa. The release of lysosomal enzymes after the ischaemia was studied by gauging the levels of acid phosphatase in the venous blood draining the ischaemic loop. The state of the mucosal microcirculation was investigated by injection of indian ink into the mesenteric artery after removal of the loop.

Immediately after ischaemia, considerable structural damage was observed in the intestinal mucosa, with desquamation of the villous tips, oedema, vascular stasis, and haemorrhagic infiltration in the lamina propria. No dye was observed in the mucosal capillaries. All transport capacity was abolished, but ATPase levels were unchanged. A significant release of lysosomal enzymes into the venous blood was noted.

One day later structural and functional recovery was complete, and vascularization of the villous core was restored.

The small intestine is notoriously sensitive to ischaemia (Rausis and Robinson, 1972; Robinson, 1972): functional and morphological damage has been observed in rats (Robinson, Antonioli, and Mirkovitch, 1966) and mice (Rao and WynnWilliams, 1969) after only 10 minutes' total ischaemia. But provided the ischaemic period is limited to less than two hours, rapid recovery of both structure and function can be expected (Robinson et al, 1966), since only the tips of the villi are affected and the crypt cells remain intact (Röttger and Oran, 1969). Drastic reduction of the blood supply has also been shown to elicit severe damage in the rabbit (David and Uerlings, 1967) and dog intestine (Passi and Lansing, 1964; Chiu, McArdle, Brown, Scott, and Gurd, 1970a). The present study was undertaken to evaluate in the dog the speed of functional and morphological recuperation after one hour's ischaemia. To keep the metabolic damage to a minimum, the intestinal loops were filled with

${ }^{1}$ Part of this work was presented to the Société Suisse de Chirurgie in April 1972, and a concise report will appear in their Proceedings (Robinson et al, 1972)

Received for publication 18 July 1972. glucose-containing buffer during the period of ischaemia, since this procedure has been shown to have a beneficial effect in restricting ischaemic deterioration (Robinson et al, 1966; Chiu, Scott, and Gurd, 1970b).

\section{Methods}

\section{SURGICAL}

Mongrel dogs of both sexes, 1-4 years old and weighing $10-25 \mathrm{~kg}$, were subjected to pentobarbital $(30 \mathrm{mg} / \mathrm{kg}$ ) anaesthesia, and total ischaemia was induced in an intestinal loop of 20 to $30 \mathrm{~cm}$ length by clamping under aseptic conditions its mesenteric artery and vein. The intestinal wall at each end of the loop was clamped to exclude collateral circulation, and the loop was filled to slight distension with Krebs bicarbonate buffer containing $0.2 \%$ glucose for the duration of the ischaemic period, which lasted 60 minutes. For recovery experiments, the clamps were removed, the incision for the injection of buffer was sutured, and the abdomen was closed.

For the determination of acid phosphatase in the venous effluent, a small incision in one branch of the 
mesenteric vein was made, and the blood collected immediately after re-establishment of the circulation. The enzyme level was determined using the Boehringer (Mannheim) colorimetric test combination.

Two parallel series of animals were used: one series provided material for the functional studies, and the other for investigation of the state of the microcirculation. For the latter, the loop was carefully excised to allow access to the mesenteric artery, which was then cannulated. The microvascular network was then washed out by injection of saline, using a pressure of up to $120 \mathrm{~mm} \mathrm{Hg}$. Then indian ink (Pelikan C 11/1431a, Pelikan-Werk, Zürich) was injected under the same pressure until macroscopic examination revealed that the entire loop had been uniformly perfused. Finally, the loop was opened, and sections were cut out for histological study.

\section{HISTOLOGY}

Samples with or without indian ink were fixed in $10 \%$ formol, embedded in paraffin, sliced $(6 \mu)$, and stained with haematoxylin-eosin.

\section{FUNCTIONAL STUDIES}

All tests were performed simultaneously on the ischaemic loop and a parallel control sample from the same dog. The parameters chosen for study included tissue water, extracellular space of mucosal slices, transport capacity in vitro for L-phenylalanine and $\beta$-methyl-D-glucoside, and levels of mucosal $\mathrm{Na}^{+}-\mathrm{K}^{+}$-ATPase and $\mathrm{Mg}^{++}$-ATPase. The intestinal loop was opened longitudinally, and divided into two parts. One part was dissected into muscular and mucosal moieties at the level of the muscularis mucosae (Robinson, Jéquier, and Felber, 1965): sections of the resultant mucosa were used for the transport studies and for the determinations of tissue water. The mucosa, free from muscle, was scraped off the other part, using a microscope slide: the ensuing extract was used for the preparation of the ATPases.

The uptake of L-phenylalanine and $\beta$-methyl-Dglucoside was determined by incubating samples of mucosa for one hour at $37^{\circ} \mathrm{C}$ in a solution of $1 \mathrm{mM}$ substrate (labelled with a tracer dose of the ${ }^{14} \mathrm{C}$ compound) dissolved in Krebs bicarbonate buffer. Parallel samples were incubated in ${ }^{14} \mathrm{COOH}$-inulin to determine the extracellular space. After the incubation, the samples were rinsed, weighed, dissolved in $30 \% \mathrm{KOH}$, and counted in a liquid scintillation counter, according to previously described techniques (Robinson and Felber, 1965). The activity was compared with that of aliquots of the incubation media which were counted under identical conditions. The water content of mucosal samples was determined by desiccation at $110^{\circ} \mathrm{C}$ overnight. Knowing the water content and the extracellular space of mucosal samples, the distribution ratio of the substrate between intra- and extracellular spaces can be readily determined from the values of substrate uptake measured.

The levels of $\mathrm{Na}^{+}-\mathrm{K}^{+}$-ATPase and $\mathrm{Mg}^{++}$-ATPase were determined in microsomal suspensions prepared from mucosal scrapings. The mucosa was homogenized in an Ultraturrax homogenizer in a mixture of $80 \% 0.3 \mathrm{M}$ saccharose and $20 \%$ Tris- $\mathrm{HCl}$ buffer

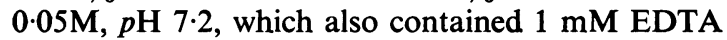
and $0.1 \%$ deoxycholate (Tris salt). The homogenate was centrifuged at $5000 \mathrm{~g}$ and the pellet was rehomogenized and re-centrifuged at the same speed. The two supernatants were then mixed and centrifuged at $75000 \mathrm{~g}$ to provide a microsomal fraction. This pellet was suspended in the same saccharose/ Tris/EDTA/DOC mixture as was used for the original homogenization. The ATPase activity was assayed by incubation of aliquots of the suspension for 10 minutes in the presence of $100 \mathrm{mM}$ imidazole/ $\mathrm{HCl}$ buffer ( $p \mathrm{H} \mathrm{7 \cdot 2),5 \textrm {mM } \mathrm { MgCl }}{ }_{2}, 100 \mathrm{mM} \mathrm{NaCl}$, $10 \mathrm{mM} \mathrm{KCl}$, and $2 \mathrm{mM} \mathrm{Na}$-ATP. Ouabain, $0.4 \mathrm{mM}$, was added to some of the tubes to inhibit the $\mathrm{Na}^{+}-$ $\mathrm{K}^{+}$-ATPase. The phosphate liberated during the incubation was determined by the method of King (1932) and the protein concentration of the original suspension by the method of Lowry, Rosebrough, Farr, and Randall (1951). In the absence of ouabain, the total ATPase is measured, whereas in the presence of the drug, only the $\mathbf{M g}^{++}$-ATPase activity can be determined. Thus the difference between the two values provides a measure of the $\mathrm{Na}^{+}-\mathrm{K}^{+}$-ATPase activity.

\section{STATISTICS}

Since each ischaemic loop is compared with its own control, differences can be evaluated by a random block analysis of variance, each animal providing one block.

\section{Results}

\section{FUNCTIONAL TESTS}

All active transport of phenylalanine and $\beta$-methylglucoside by the intestinal mucosa is abolished after one hour's acute ischaemia, even if the lumen contains a glucose-containing buffer solution during the ischaemic period. The distribution ratios, as seen in Table I, do not differ from unity. The extracellular space and the water content of the mucosa, however, remain unchanged. On the other hand, the transport capacity is already indistinguishable from that of the control loops 24 hours after the end of the ischaemic period. The small reduction in $\beta$-methyl-glucoside 


\begin{tabular}{|c|c|c|c|c|c|c|c|c|c|}
\hline & \multicolumn{2}{|c|}{ Phenylalanine Transport } & \multicolumn{2}{|c|}{$\begin{array}{l}\text { B-Methyl-glucoside } \\
\text { Transport }\end{array}$} & \multicolumn{2}{|c|}{ Extracellular Space } & \multicolumn{2}{|c|}{ Tissue Water } & \multirow[t]{2}{*}{ No. } \\
\hline & Control & Ischaemic & Control & Ischaemic & Control & Ischaemic & Control & Ischaemic & \\
\hline $\begin{array}{l}\text { Immediately after } \\
\text { ischaemia }\end{array}$ & $\begin{array}{c}10.43 \pm \\
0.383\end{array}$ & $\begin{array}{l}1 \cdot 17 \pm \\
0.265\end{array}$ & $\begin{array}{l}9.06 \pm \\
0.408\end{array}$ & $\begin{array}{l}1 \cdot 12 \pm \\
0 \cdot 267\end{array}$ & $\begin{array}{c}12 \cdot 3 \pm \\
1 \cdot 84\end{array}$ & $\begin{array}{c}14 \cdot 2 \pm \\
3 \cdot 86\end{array}$ & $\begin{array}{c}81.68 \pm \\
0.385\end{array}$ & $\begin{array}{c}81 \cdot 78 \pm \\
0.758\end{array}$ & 8 \\
\hline $\begin{array}{l}\text { One day after } \\
\text { ischaemia }\end{array}$ & $\begin{array}{l}8 \cdot 58 \pm \\
0.747\end{array}$ & $\begin{array}{l}8.61 \pm \\
0.640\end{array}$ & $\begin{array}{l}7 \cdot 47 \pm \\
0.802\end{array}$ & $\begin{array}{l}6.37 \pm \\
0.627\end{array}$ & $\begin{array}{c}16.9 \pm \\
1.00\end{array}$ & $\begin{array}{c}17 \cdot 9 \pm \\
1 \cdot 34\end{array}$ & $\begin{array}{c}81 \cdot 49 \pm \\
0.179\end{array}$ & $\begin{array}{c}81.67 \pm \\
0.413\end{array}$ & 8 \\
\hline $\begin{array}{l}\text { Three days after } \\
\text { ischaemia }\end{array}$ & $\begin{array}{l}9.92 \pm \\
0.979\end{array}$ & $\begin{array}{c}11.41 \\
1.521\end{array}$ & $\begin{array}{l}9 \cdot 21 \pm \\
1 \cdot 433\end{array}$ & $\begin{array}{l}8 \cdot 24 \pm \\
1 \cdot 537\end{array}$ & $\begin{array}{l}14.6 \pm \\
1.42\end{array}$ & $\begin{array}{c}15 \cdot 8 \pm \\
1 \cdot 19\end{array}$ & $\begin{array}{c}80.62 \pm \\
0.375\end{array}$ & $\begin{array}{c}80.56 \pm \\
0.411\end{array}$ & 9 \\
\hline
\end{tabular}

Table I Transport parameters in control and ischaemic intestinal loops ${ }^{1}$

${ }^{1}$ Paired ischaemic and control loops tested simultaneously. Transport expressed as distribution ratios between intra- and extracellular spaces, extracellular space (inulin space), and tissue water as percentages. The only significant differences concern the transports of phenylalanine and $\beta$-methyl-glucoside immediately after the ischaemia.

transport at this stage just fails to reach the 5\% significance limit $\left(F_{1.7}=5 \cdot 24\right)$.

Despite the abolition of amino-acid and sugar transport, the levels of $\mathrm{Na}^{+}-\mathrm{K}^{+}$-ATPase in mucosal scrapings is unchanged at the end of the ischaemic period (Table II). A similar temporal dissociation between the loss of transport capacity and the diminution of $\mathrm{Na}^{+}-\mathrm{K}^{+}$-ATPase activity has been observed in colons subjected to acute ischaemia (Rausis and Robinson, 1971; Rausis, Robinson, Mirkovitch, and Saegesser, 1972) and has been interpreted as indicating that transport dysfunctions appear in the cellular membrane before destruction of cellular enzymatic components is initiated.

\begin{tabular}{|c|c|c|c|c|c|}
\hline \multirow{2}{*}{$\begin{array}{l}\text { Days after } \\
\text { Ischaemia }\end{array}$} & \multicolumn{2}{|c|}{$\mathrm{Na}^{+}-\mathrm{K}^{+}-\mathrm{ATPase}$} & \multicolumn{2}{|c|}{$\mathrm{Mg}^{++}-A T P a s e$} & \multirow[t]{2}{*}{ No. } \\
\hline & Control & Ischaemic & Control & Ischaemic & \\
\hline Immediately & $\begin{array}{r}243 \\
40\end{array}$ & $\frac{254}{33} \pm$ & $\begin{array}{c}152 \\
13\end{array}$ & $\begin{array}{c}125 \\
20\end{array}$ & 8 \\
\hline One day & $\frac{385}{48} \pm$ & $\frac{349}{46} \pm$ & $\begin{array}{c}192 \\
17\end{array}$ & $\begin{array}{c}200 \\
13\end{array}$ & 8 \\
\hline Three days & $\begin{array}{c}315 \\
20\end{array}$ & $\begin{array}{r}316 \\
21\end{array}$ & $\begin{array}{c}174 \\
10\end{array}$ & $\begin{array}{c}184 \\
15\end{array}$ & 9 \\
\hline
\end{tabular}

Table II ATPase levels in control and ischaemic intestinal loops ${ }^{1}$

${ }^{1}$ Enzymes from control and ischaemic loops prepared in parallel. Values expressed $( \pm$ SEM) in n-moles phosphate liberated $/ \mathrm{min} / \mathrm{mg}$ protein. No significant differences between values for control and ischaemic loops within the same series.

\section{LYSOSOMAL ENZYME LEVELS}

The resting level of acid phosphatase in the left iliac vein of 27 dogs has been found to be $6.2 \pm 0.50$ units (Borgeaud, 1972), the unit being defined as the number of micromoles of phosphate liberated per minute per litre of plasma. The acid phosphatase level in the venous effluent of 24 dogs after one hour's acute ischaemia was $11.7 \pm 1.26$ units; this represents a highly significant increase over the control values $(t=4.09 ; \mathrm{P}<0.001)$.

\section{MICROCIRCULATION AND HISTOLOGY}

The injection of indian ink permits the study of the capillary circulation reaching the base of the epithelial cells at the tips of the villi (Fig. 1).

The histological picture of the dog's intestine after one hour's ischaemia is one of infarction (Fig. 2). There is extensive desquamation from the villous tips, with oedema and haemorrhagic infiltration of the lamina propria, accompanied by considerable vascular congestion. The crypt cells remain, however, relatively intact. The microcirculatory studies show (Fig. 3) that the indian ink no longer proceeds to the tips of the villi, despite the fact that the tissue had been washed out with saline before injection of the ink. Furthermore, at the base of the villi, it is possible to discern vessels that contain both indian ink and plugs of agglutinated erythrocytes (Fig. 4).

One day after the end of the ischaemic period, the histology of the intestine appears almost normal (Fig. 5), though in some cases an accumulation of

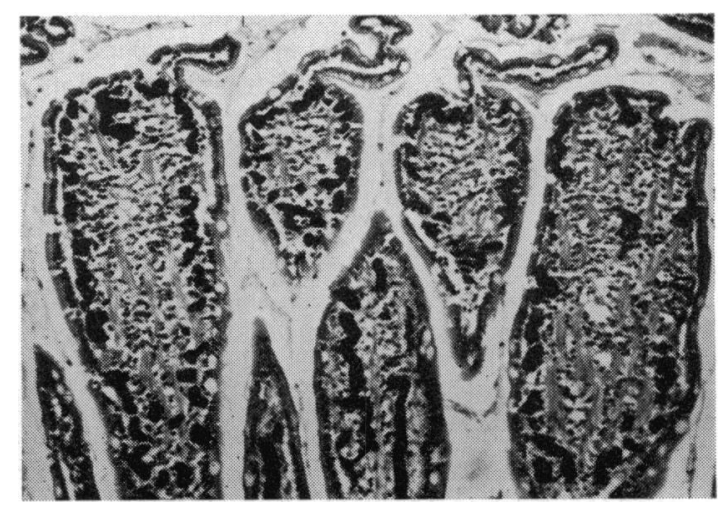

Fig. 1 Normal intestine injected with indian ink and stained with haemotoxylin-eosin, showing the presence of contrast at the base of the epithelial cells $(\times 160)$. 


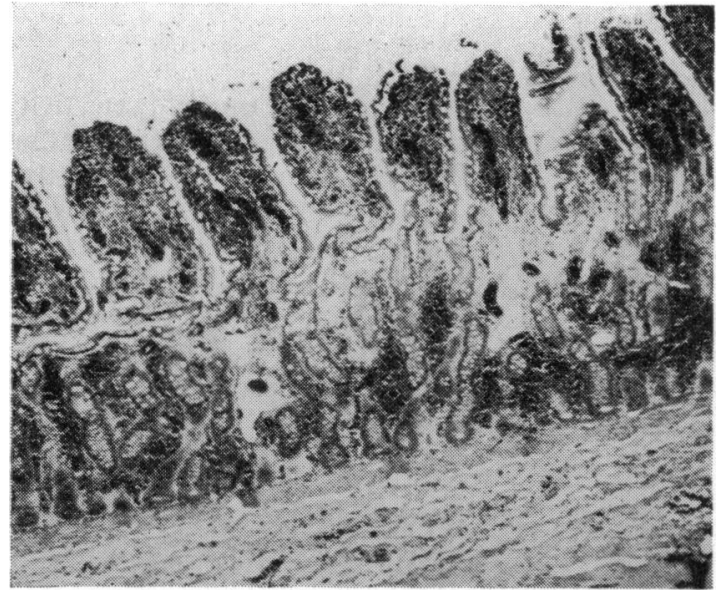

Fig. 2

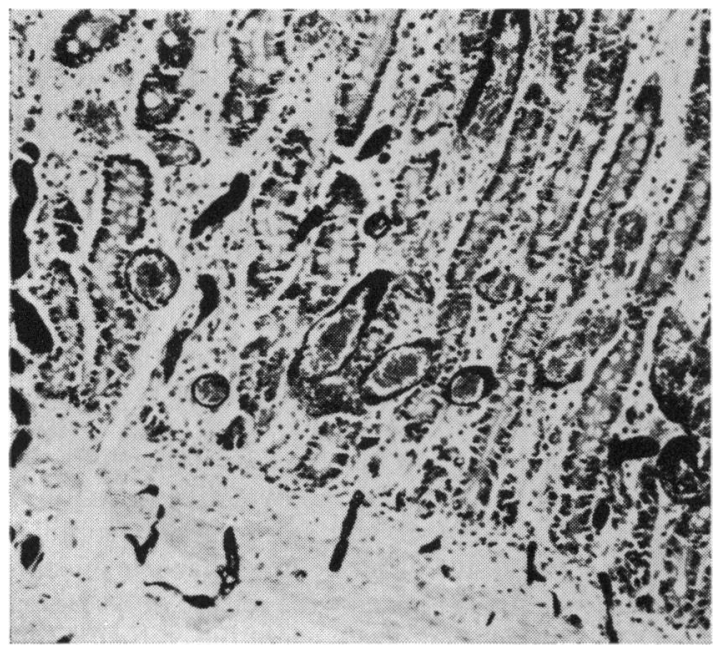

Fig. 4

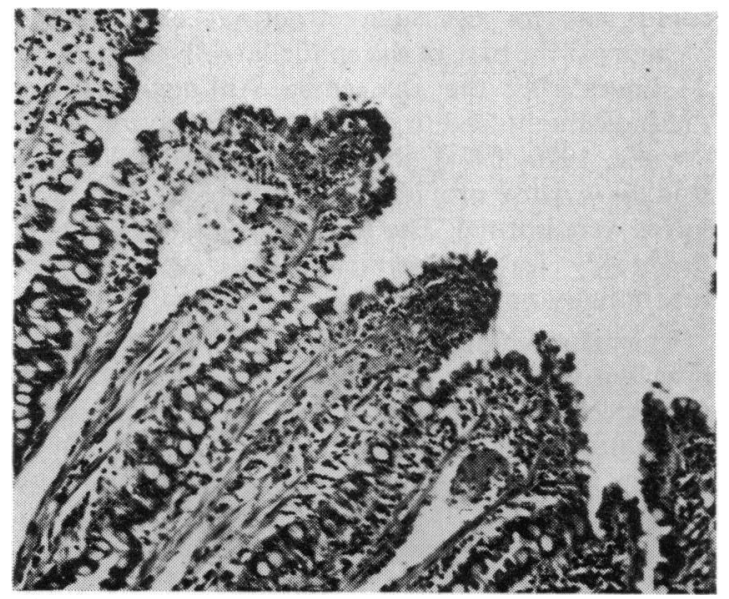

Fig. 6

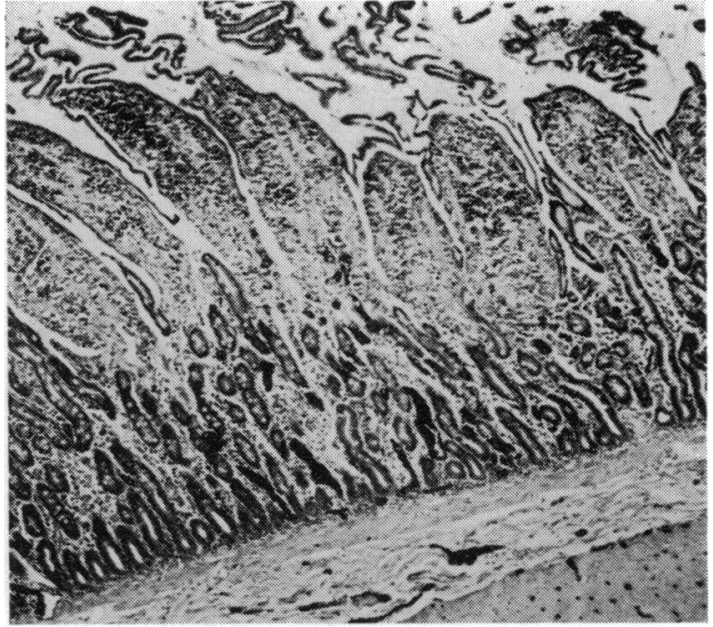

Fig. 3

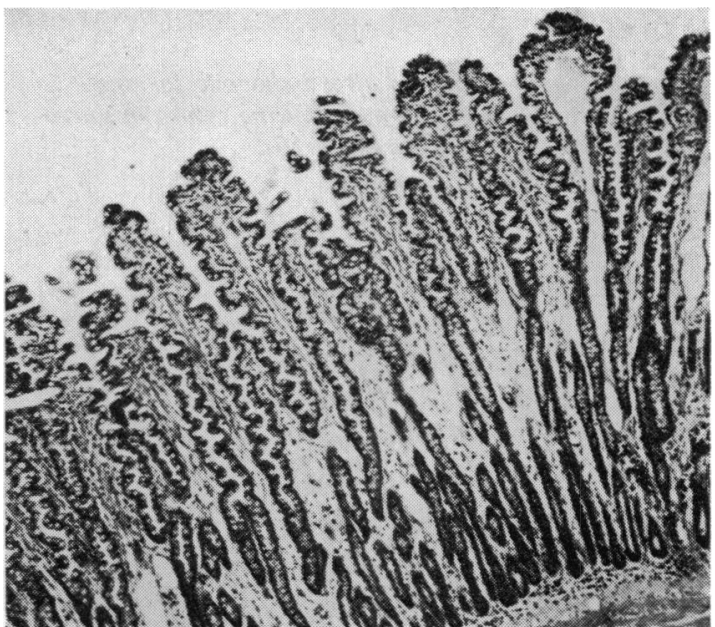

Fig. 5

Fig. 2 Intestine immediately after one hour's ischaemia in the presence of luminal glucose buffer. Stained with haematoxylin-eosin $(\times 65)$.

Fig. 3 Ischaemic intestine, injected with indian ink, immediately after the end of ischaemia for one hour. Note the absence of dye in villous cores $(x 65)$.

Fig. 4 Bases of villi from ischaemic intestine, injected with indian ink, showing vessels containing both ink and agglutinated erythrocytes $(\times 160)$.

Fig. 5 Intestine 24 hours after ischaemia for one hour, showing an almost normal histological picture $(\times 55)$.

Fig. 6 Intestine 24 hours after ischaemia for one hour, showing a residue of erythrocytes near villous tips $(\times 160)$. 


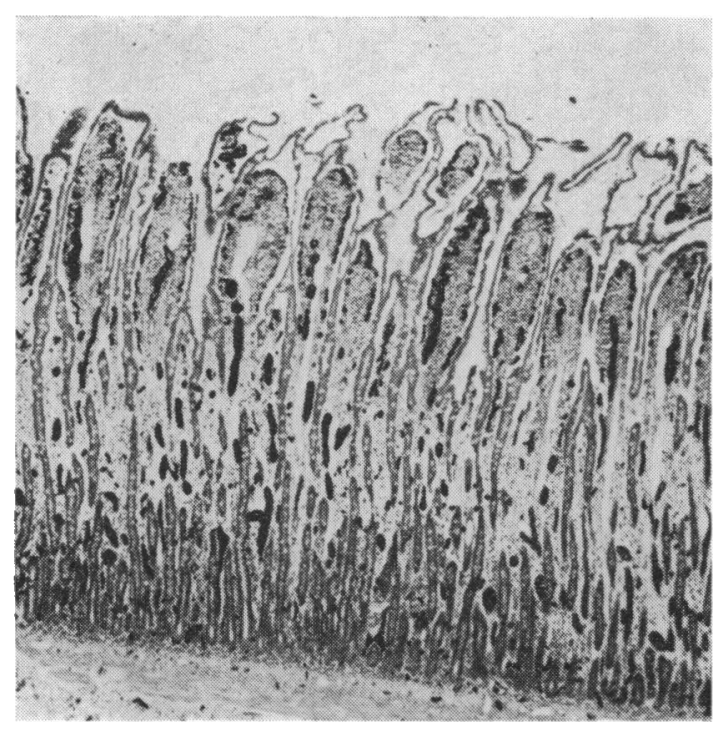

Fig. 7 Intestine 24 hours after ischaemia for one hour, injected with indian ink, showing return of microperfusion to the villous cores $(\times 50)$.

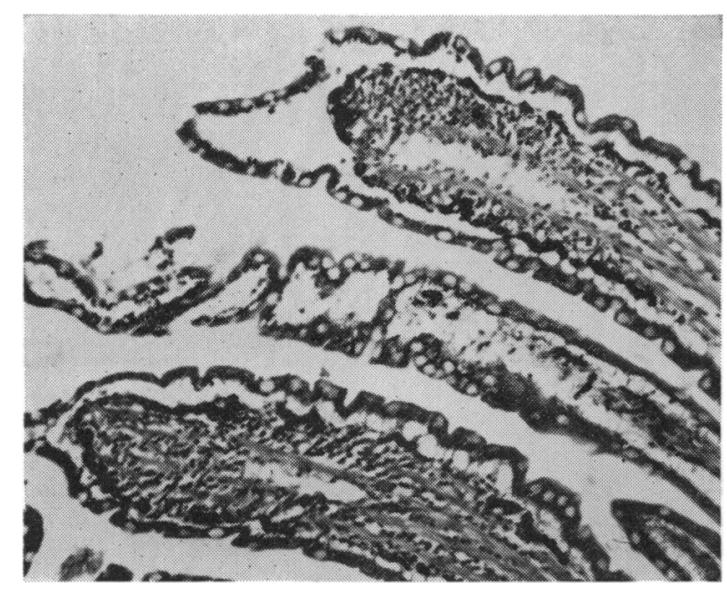

Fig. 8 Intestine 24 hours after ischaemia for one hour, injected with indian ink, showing the reopening of microcirculation to the bases of the epithelial cells and obvious oedema beneath the cells $(\times 140)$.

residual erythrocytes at the tips of the villi (Fig. 6) or oedema below the epithelial cells (as in Fig. 8) may be observed. The microcirculation had normalized in almost all specimens (Fig. 7), and now the dye once again attained the bases of the epithelial cells at the tips of the villi (Fig. 8).

\section{Discussion}

The present results underline the unusual sensitivity of the small intestinal mucosa to acute ischaemia and demonstrate its tremendous regenerative potential, provided the crypt cells remain intact. Previous work (Röttger and Oran, 1969) has indicated that the crypt zone is only damaged in the rat intestine after two hours' ischaemia; this is due, presumably, to the considerably smaller number of lysosomal granules in the immature crypt cells (Riecken, Stewart, and Dowling, 1966).

The appearance of increased levels of acid phosphatase in the venous effluent immediately after ischaemia, as was also found by others (Bounous and McArdle, 1969; Röttger and Oran, 1969), indicates that lysosomal enzymes are involved in the necrotic process. Chiu et al (1970a) have, however, presented evidence suggesting that the production of oedema in the lamina propria, particularly just below the epithelial cells, precedes the rupture of lysosomal membranes. This stage had obviously been passed in the present work, though the oedema observed beneath the epithelial cells during the recovery stage (Fig. 8) may be a reflection of the same phenomenon, apparently caused by the vascular stasis (Chiu et al, 1970a). Winne $(1970,1971)$ has pointed out that reduction of the blood flow has at least three effects on the intestine, namely, a labilization of the lysosomal membrane due to anoxia which leads to tissue necrosis, a reduction in the drainage of the epithelial cells, and a diminution in the oxidative metabolism of the cells with consequent loss in energy supplies. The principal result of an acute ischaemia of more than a few minutes is clearly the release of lysosomal enzymes. But deficient drainage of the epithelial cells resulting from disturbances in the microcirculation could lead to just such structural abnormalities (oedema at the base of the epithelial cells) as were seen 24 hours after the ischaemia. Although deficient drainage might lead to diminished absorption in vivo (Winne, 1970, 1971), this would not be reflected in studies in vitro provided the epithelial cells themselves were normal. The present results indicate that the newly formed epithelial covering is in fact functionally normal.

The microcirculation studies demonstrate that one hour's ischaemia leads to a complete arrest of the microperfusion of the villous core. Previous investigators have suggested that the microcirculation can be disturbed by the opening of arteriovenous anastomoses in certain pathological states (Varró, 1966). It must be assumed that these short-circuit pathways are used when the circulation in the villous core is blocked. 
This work was supported in part by a grant from Zyma, S.A., Nyon, Suisse. We are grateful to our colleagues Drs C. Rausis, A. Fischer and B. Winistörfer for assisting with the operations, and to Professor J. Frei and his staff for the determinations of acid phosphatase: We are indebted to Mme $\mathrm{Z}$. Simićević for the preparation of the histological slides, to Mlles C. Brandt and U. Päßler for biochemical assistance, and to Mlle J. Vouron for help with the surgical preparations.

\section{References}

Borgeaud, J. (1972). Fonction, microcirculation, enzymes lysosomales et transport actif lors d'ischémies ou de transplantations rénales. MD Thesis, Faculty of Medicine, Lausanne University.

Bounous, G., and McArdle, A. H. (1969). Release of intestinal enzymes in a cute mesenteric ischemia.J. surg. Res., 9, 339-346.

Chiu, C. J., McArdle, A. H., Brown, R., Scott, H. J., and Gurd, F. N. (1970a). Intestinal mucosal lesion in low-flow states. I. A morphological, hemodynamic and metabolic reappraisal. Arch. Surg., 101, 478-483.

Chiu, C. J., Scott, H. J., and Gurd, F. N. (1970b). Intestinal mucosal lesion in low-flow states. II. The protective effect of intraluminal glucose as energy substrate. Arch. Surg., 101, 484-488.

David, H., and Uerlings, I. (1967). Elektronenmikroskopische Befunde am Dünndarm des Kaninchens nach Gefässunterbindung. Exp. Path. (Jena), 1, 30-44.

King, E. J. (1932). The colorimetric determination of phosphorus. Biochem. J., 26, 292-297.

Lowry, O. H., Rosebrough, N. J., Farr, A. L., and Randall, R. J. (1951). Protein measurement with the Folin phenol reagent. J. biol. Chem., 193, 265-275.

Passi, R. B., and Lansing, A. M. (1964). Experimental intestinal malabsorption produced by vascular insufficiency. Canad. J. Surg., 7, 332-340.
Rao, S. N., and Wynn-Williams, A. (1969). A comparison of postmortem and ischaemic changes in the absorptive cells of the jejunal mucosa in mice. Proc. Univ. Otago med. Sch., 47, 89-91.

R.ausis, C., and Robinson, J. W. L. (1971). Ischémie colique aiguë et transitoire: de la recherche expérimentale aux faits cliniques. Méd. Hyg. (Genève), 29, 1356.

Rausis, C., and Robinson, J. W. L. (1972). Sensibilité de la muqueuse intestinale à l'insuffisance circulatoire. Praxis, 61, 217-219.

Rausis, C., Robinson, J. W. L., Mirkovitch, V., and Saegesser, F. (1972). Ischémie colique nécrosante et gangreneuse: faits cliniques et recherche expérimentale. Helv. chir. Acta, 39, 251258.

Riecken, E. O., Stewart, J. S., and Dowling, R. H. (1S66). Neuere Methodik in der Diagnostik intestinaler Störungen. Internist, 7, 209-217.

Robinson, J. W. L. (1972). Experimental intestinal malabsorption states and their relation to clinical syndromes. Klin. Wschr., 50, 173-185.

Robinson, J. W. L., Antonioli, J. A., and Mirkovitch, V. (1966). The intestinal response to ischaemia. Naunyn-Schmiedeberg's Arch. Pharmak. exp. Path., 255, 178-191.

Robinson, J. W. L., and Felber, J. P. (1965). Compartments of the uptake of amino-acids by intestinal fragments during in vitro incubation. Gastroenterologia (Basel), 104, 335-342.

Robinson, J. W. L., Jéquier, J. Cl, and Felber, J. P. (1965). The accumulation of amino acids by various preparations of dog intestine. Experientia (Basel), 21, 12-13.

Rebinson, J. W. L., Mirkovitch, V., and Rausis, C. (1972). Récupération fonctionnelle et morphologique de l'intestin grêle de chien après ischémie aiguë. Helv. chir. Acta, in press.

Röttger, P., and Oran, M. (1969). Histochemische und biochemische Untersuchungen zur Frage des Enzym-Gehaltes der Dünndarmschleimhaut nach temporärer Ischämie. Verh. dtsch. Ges. Path., 53, 189-193.

Varró, V. (1966). Die Beziehungen zwischen Resorption und Blutzirkulation im Dünndarm. Internist, 7, 250-255.

Winne, D. (1970). Der Einfluss der Durchblutung auf die Wasser- und Salzresorption im Jejunum der Ratte. Naunyn-Schmiedeberg's Arch. Pharmak. exp. Path., 265, 425-441.

Winne, D. (1971). Durchblutung und enterale Resorption. Z. Gastroent., 9, 429-441. 